\title{
EDITORIAL
}

\section{INTRODUCTION EDITORIAL}

It has been another successful year of the Brazilian Dental Science journal, establishing itself as a qualified international journal.

Some of the most expressive achievements within this period are: periodicity, editorial quality, comprehensive reviewers team involving all Brazilian states and all continents of the world, presence of international section editors and co-editors with a significant position in the global research, involvement of Latin America in publication and dissemination of the journal, strong presence in leading research conferences in Americas, Europe and Asia, credibility of researchers in submitting their work, average between manuscript submission and acceptance of five months, and redesigned website in international language to better serve the target audience.

Thus, the editorial board expects recognition by the most significant databases, on the immense progress made with effort of a particular group in order to offer researchers another quality vehicle for dissemination of their research results.

In this sense, I present the editorial written by renowned researchers, who kindly wrote a compilation of the most relevant topics of the Laser Symposium, held in September 2015, during the SBPqO, Brazilian Division of the IADR. I had the great pleasure of being the moderator of presentations and discussions during the symposium, where I had he idea of launching this compilation of discussions in the BDS journal. The cover of this volume was chosen to celebrate this important event in the context of Brazilian research and to encourage everyone to share the published articles, related to Laser or other significant subjects.

Sincerely,

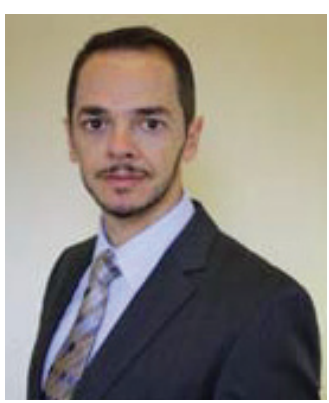

Associate Professor

Sérgio Eduardo de Paiva Gonçalves Editor-in-Chief 


\section{EDITORIAL}

\section{EDITORIAL DE APRESENTAÇÃO}

Mais um ano de sucesso da Brazilian Dental Science, firmando-se como uma revista de qualidade internacional.

Periodicidade, qualidade editorial, quadro de revisores abrangente envolvendo todos os estados brasileiros e todos os continentes do mundo, editores de área internacionais, coeditores com expressiva posição no cenário da pesquisa mundial, envolvimento da América Latina na publicação e na divulgação do periódico, presença marcante em congressos de impacto no contexto da pesquisa nas Américas, Europa e Ásia, credibilidade de pesquisadores na submissão de seus trabalhos, média entre submissão e aceite de 5 meses, site reformulado para atender melhor ao público alvo e em linguagem internacional, representam algumas das mais expressivas conquistas desse período.

Assim, a comissão editorial espera pelo reconhecimento das mais significativas bases de dados, do imenso progresso conseguido com o trabalho e esforço de um grupo determinado a oferecer aos pesquisadores, mais um veículo de qualidade para divulgação de resultados em pesquisa.

Nesse sentido, seguimos com o editorial escrito por renomados pesquisadores, que gentilmente realizaram uma compilação dos tópicos mais relevantes do Simpósio de Laser, ocorrido em setembro de 2015, durante a SBPqO, divisão brasileira da IADR. Tive o imenso prazer de ser o moderador das apresentações e discussões durante o simpósio, de onde surgiu a idéia de lançar na BDS uma compilação das discussões. A capa desse volume foi escolhida para celebrar esse importante evento no contexto da pesquisa brasileira e convidar a todos para compartilhar dos artigos sobre este e outros assuntos também significativos aqui publicados.

Sinceramente,

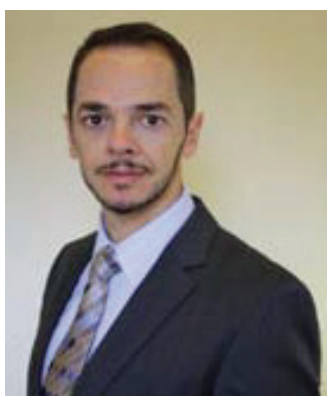

Associate Professor

Sérgio Eduardo de Paiva Gonçalves Editor-in-Chief 


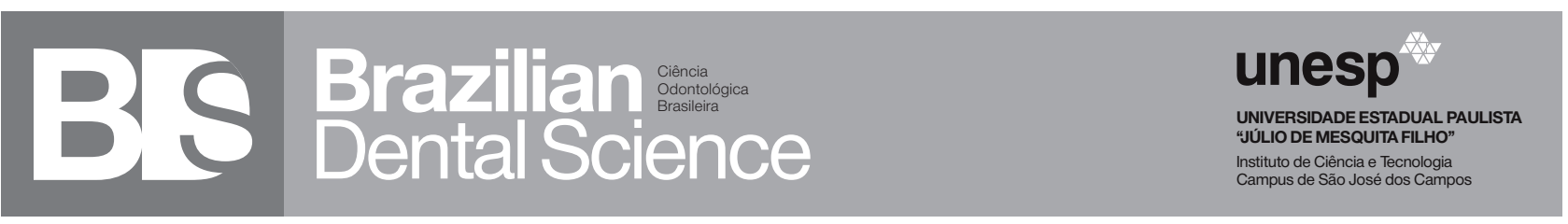

\section{EDITORIAL}

\section{LASER PANORAMA IN DENTISTRY IN THE INTERNATIONAL YEAR OF LIGHT}

The use of laser in Dentistry was under discussion on the $32^{\text {nd }}$ Annual Meeting of the Brazilian Society for Dental Research (SBPqO), the largest scientific research event in Dentistry in Brazil, which was held between $4^{\text {th }}$ and $7^{\text {th }}$ September 2015, at Expo Dom Pedro annexed to the Parque D. Pedro Shopping, in Campinas. Professors, researchers, undergraduate and graduate students from various Brazilian and international Universities attended this meeting. About 4,000 participants presented 3,155 scientific papers in all areas of Dentistry. Entity data show that Brazil has distinguished itself worldwide in the dental research area, being ranked as the third most important country, behind only the United States $\left(1^{\text {st }}\right)$ and Japan $\left(2^{\text {nd }}\right)$.

Laser clinical application goes far beyond whitening teeth techniques and aesthetics. Scientific evidences, along with technological developments, allow dentists to use low-power laser for modulating inflammatory processes, pain relief, and acceleration of tissue repair. Low power laser can be a great tool in the dental clinic, providing patients greater well-being and reduced recovery time when used with solid knowledge of its mechanisms of action. Several factors influence the efficacy of this therapy, such as light -related parameters (wavelength, energy, and exposure time), the clinical condition and individual patient characteristics (age, immunocompetence), and optical characteristics of the target tissue (color, structure and thickness).

High-power lasers have been used for surgical treatment of lesions, such as benign tumors, vascular lesions, and potentially malignant oral disorders. The use of such lasers as an effective tool for treating extensive lesions has produced benefits to patients compared to conventional techniques, such as the control of bleeding, thus providing better visualization of the surgical field, reducing the time of the procedure, as well as reducing bacteremia.

Brazil is the country with more publications abroad related to the use of lasers in Dentistry and in the offices, lasers are a consolidated working tool. However, the use of lasers needs to be more spread among professionals, increasing commitment, and scientific knowledge on the subject.

Finally, on the International Year of Light, proclaimed by the United Nations to highlight the importance of light-based technologies, the Laser Symposium in Dentistry at the $32^{\text {nd }}$ Research Meeting SBPqO was a unique opportunity to discuss the clinical use of laser technology based on scientific evidence, in various specialties of Dentistry.

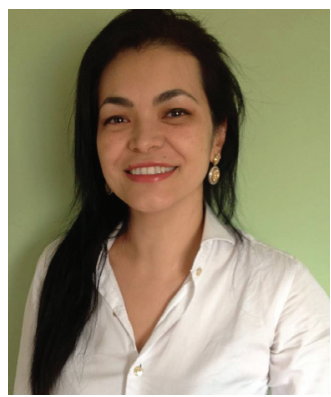

Luciane Hiramatsu Azevedo Faculdade de Odontologia - USP Universidade de São Paulo

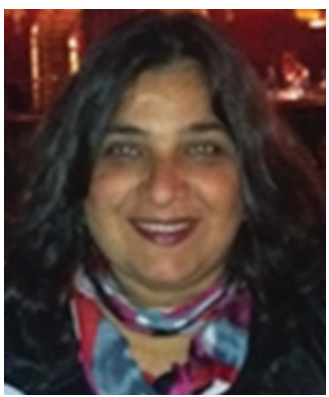

Martha Simões Ribeiro Instituto de Pesquisas Energéticas e Nucleares

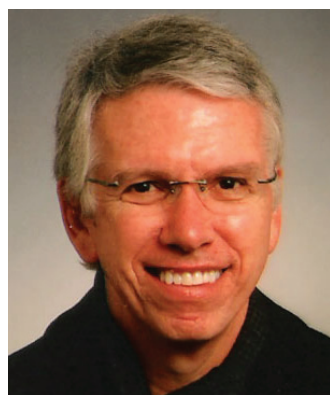

Carlos de Paula Eduardo Faculdade de Odontologia - USP Universidade de São Paulo 


\section{EDITORIAL}

\section{PANORAMA DO LASER EM ODONTOLOGIA NO ANO INTERNACIONAL DA LUZ}

A utilização do laser na Odontologia esteve em discussão durante a $32^{\mathrm{a}}$ Reunião Anual da Sociedade Brasileira de Pesquisa Odontológica (SBPqO), maior evento científico de pesquisa em odontologia do Brasil, que foi realizada entre os dias 4 e 7 de setembro de 2015, no Expo Dom Pedro, anexo ao Parque D. Pedro Shopping, em Campinas. Essa reunião contou com a presença de professores, pesquisadores, alunos de graduação e pós-graduação de diversas universidades brasileiras e internacionais. Foram cerca de 4 mil participantes que apresentaram 3.155 trabalhos científicos em todas as áreas da odontologia. Dados da entidade apontam que o Brasil tem se destacado em nível mundial na área de pesquisa odontológica, sendo classificado como terceiro mais importante país, atrás somente dos Estados Unidos $\left(1^{\circ}\right)$ e Japão $\left(2^{\circ}\right)$.

A aplicação clínica do laser vai muito além das técnicas de clareamento dos dentes e da questão estética. Evidências científicas, junto à evolução tecnológica, fazem com que cirurgiões-dentistas utilizem o laser de baixa potência para modulação de processos inflamatórios, alívio de dor e aceleração de reparo tissular. O laser de baixa potência pode ser uma ótima ferramenta na clínica odontológica, oferecendo aos pacientes maior bem estar e tempo de recuperação reduzido, quando empregado com conhecimentos sólidos sobre os seus mecanismos de ação. Diversos fatores influenciam na eficácia desta terapia, como os parâmetros relacionados à luz (comprimento de onda, energia, tempo), a condição clínica e características individuais do paciente (idade, imunocompetência) e características ópticas do tecido alvo (coloração, estrutura, espessura).

Já os lasers de alta potência têm sido utilizados para tratamento cirúrgico de lesões como tumores benignos, lesões vasculares e lesões potencialmente cancerizáveis. A utilização desses lasers como instrumento eficaz para tratamento de lesões extensas tem produzido benefícios aos pacientes em relação às técnicas convencionais, tais como o controle do sangramento, proporcionando, assim, melhor visualização do campo cirúrgico, reduzindo o tempo do procedimento, além da redução da bacteremia.

O Brasilé um dos países com mais publicações no exterior relacionadas ao uso do laser em odontologia e, nos consultórios, é uma ferramenta de trabalho consolidada. No entanto, é necessário que haja mais divulgação entre os profissionais e cada vez mais comprometimento e conhecimento científico sobre o assunto.

Por fim, no Ano Internacional da Luz, proclamado pela ONU para destacar a importância das tecnologias baseadas em luz, o Simpósio de Laser em Odontologia durante a $32^{\mathrm{a}}$ Reunião de Pesquisa da SBPqO foi uma oportunidade ímpar para poder se discutir a utilização clínica da tecnologia laser, baseada em evidências científicas, nas diversas especialidades da Odontologia.

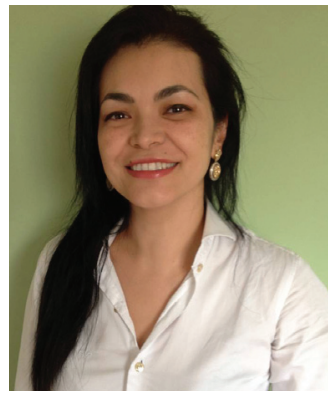

Luciane Hiramatsu Azevedo Faculdade de Odontologia - USP -

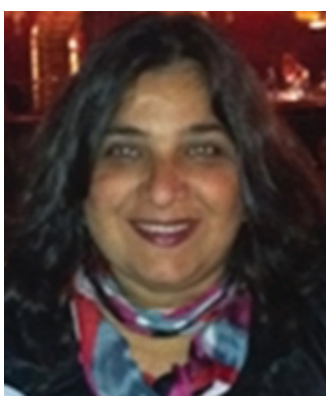
Universidade de São Paulo

Martha Simões Ribeiro

Instituto de Pesquisas Energéticas e Nucleares

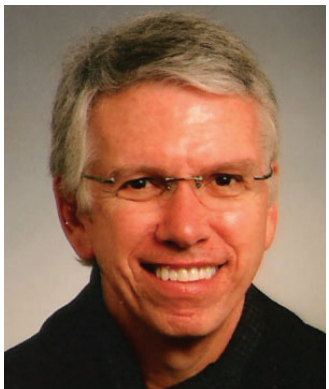

Carlos de Paula Eduardo

Faculdade de Odontologia - USP Universidade de São Paulo 